\title{
Phytochemistry and Pharmacology of Thymus broussonetii Boiss
}

\author{
Hanae Naceiri Mrabti $\left(\mathbb{D},{ }^{1}\right.$ Latifa Doudach, ${ }^{2}$ Naoual El Menyiy $\mathbb{D}^{3}{ }^{3}$ Mohammed Bourhia, ${ }^{4}$ \\ Ahmad Mohammad Salamatullah $\left(\mathbb{D},{ }^{5}\right.$ Mohamed Reda Kachmar $\left(\mathbb{D},{ }^{6}\right.$ Omar Belmehdi, \\ Hamza El Moudden $\mathbb{D D}^{8}{ }^{8}$ Nidal Naceiri Mrabti, ${ }^{9}$ Hicham Harhar ${ }^{\circ},{ }^{8}$ \\ Nasreddine El Omari $\mathbb{D},{ }^{10}$ and Abdelhakim Bouyahya $\mathbb{D D}^{11}$
}

${ }^{1}$ Laboratory of Pharmacology and Toxicology, Bio Pharmaceutical and Toxicological Analysis Research Team, Faculty of Medicine and Pharmacy, Mohammed V University in Rabat, BP 6203, Rabat, Morocco

${ }^{2}$ Biomedical Engineering Department, National School of Arts and Crafts Rabat (ENSAM), Mohammed V University in Rabat, BP 6203, Rabat, Morocco

${ }^{3}$ Faculty of Sciences Dhar El Mahraz, Sidi Mohamed Ben Abdellah University, Fez, Morocco

${ }^{4}$ Laboratory of Chemistry-Biochemistry, Environment, Nutrition and Health, Faculty of Medicine and Pharmacy, Hassan II University, Casablanca 21100, Morocco

${ }^{5}$ Department of Food Science \& Nutrition, College of Food and Agricultural Sciences, King Saud University, P.O. Box 2460, Riyadh 11451, Saudi Arabia

${ }^{6}$ Faculty of Sciences, Health and Environment Laboratory, Plant Protection Team, Moulay Ismail University, Meknes, BP 11201, Zitoun, Morocco

${ }^{7}$ Biology and Health Laboratory, Department of Biology, Faculty of Science, Abdelmalek-Essaadi University, Tetouan, Morocco

${ }^{8}$ Laboratory of Materials, Nanotechnology and Environment, Department of Chemistry, Faculty of Sciences, Mohammed V University in Rabat, Rabat, Morocco

${ }^{9}$ Computer Chemistry and Modeling Team, Laboratory of Materieals, Modeling and Environmental Engineering, LIMME, Faculty of Sciences Dhar El Mehraz, Sidi Mohammed Ben Abdellah University, Fes, Morocco

${ }^{10}$ Laboratory of Histology, Embryology, and Cytogenetic, Faculty of Medicine and Pharmacy, Mohammed V University, Rabat, Morocco

${ }^{11}$ Laboratory of Human Pathologies Biology, Department of Biology, Faculty of Sciences, and Genomic Center of Human Pathologies, Faculty of Medicine and Pharmacy, Mohammed V University, Rabat, Morocco

Correspondence should be addressed to Abdelhakim Bouyahya; boyahyaa-90@hotmail.fr

Received 4 June 2021; Revised 15 August 2021; Accepted 26 August 2021; Published 6 September 2021

Academic Editor: Dejan Stojkovic

Copyright (C) 2021 Hanae Naceiri Mrabti et al. This is an open access article distributed under the Creative Commons Attribution License, which permits unrestricted use, distribution, and reproduction in any medium, provided the original work is properly cited.

Thymus broussonetii Boiss (T. broussonetii) is a rare medicinal and aromatic plant. It is widely used in traditional medicine to treat several diseases, including diarrhea, fever, cough, irritation, skin diseases, rheumatism, respiratory ailments, influenza, and digestion problems. In this review, we have critically summarized previous data on T. broussonetii about its phytochemistry, botanical and geographical distribution, toxicological investigation, and pharmacological properties. Using scientific research databases such as Wiley Online, SciFinder, ScienceDirect, PubMed, SpringerLink, Web of Science, Scopus Wiley Online, and Google Scholar, the data on T. broussonetii were collected and discussed. The presented data regrouped bioactive compounds and biological activities of T. broussonetii. The findings of this work showed that essential oils and extracts of $T$. broussonetii exhibited numerous pharmacological activities (in vitro and in vivo), particularly antibacterial, antifungal, antioxidant, anticancer, anti-inflammatory, insecticidal, antipyretic, antinociceptive, and immunological and behavioral effects. While toxicological studies of T. broussonetii essential oils and extracts are lacking, modern scientific tools revealed the presence of different classes of secondary metabolites such as terpenoids, alkaloids, flavonoids, tannins, coumarins, quinones, carotenoids, and steroids. T. broussonetii essential oils, especially from the aerial parts, exhibited potent antibacterial, antifungal, and antioxidant effects. An in-depth 
toxicological investigation is needed to validate the efficacy and safety of T. broussonetii extracts and essential oils and their secondary metabolites. However, further pharmacokinetic and pharmacodynamic studies should be performed to validate its bioavailability.

\section{Introduction}

Thymus broussonetii Boiss (Thymus broussonetii) belongs to the Lamiaceae family and the genus of Thymus. It is a small shrub of $40 \mathrm{~cm}$ in height and is endemic to Morocco, Algeria, and Tunisia [1]. It is known locally in Morocco as "Zaitra," "Tazouknnit," or "Azukni" [2, 3]. T. broussonetii is distributed on the Atlantic coast between 20 and $400 \mathrm{~m}$ altitude and is mainly located in arid and semiarid bioclimatic zones [4].

It is among the plants most used in Moroccan folk medicine against various illnesses such as urinary, nervous, genital, circulatory, skin, digestive, and respiratory diseases $[2,3]$. It is also used to treat diabetes $[3,5,6]$, cold, cough, fever, digestive disorders, and dolorous processes [7]. Other researchers have reported the use of this plant in food as a seasoning of traditional recipes (seasoning) and to flavor tea or milk [8]. Ethnobotanical surveys are the first step to identify the plant uses for each disorder. It provides information on the part used, the method of preparation, etc. However, the lack of plant information given by researchers in many surveys was repeatedly noticed. This is the case of several researchers who reported the use of T. broussonetii in folk medicine without mentioning the part used, the method of preparation, or/and the traditional use $[9,10]$.

Several classes of bioactive compounds, including flavonoids, alkaloids, terpenoids, tannins, coumarins, quinones, steroids, and carotenoids, have been identified in essential oils (EOs) and extracts of $T$. broussonetii, which explains its biological activities [11-25].

Using in vitro and in vivo pharmacological approaches, researchers reported the potential activity of $T$. broussonetii extracts and EOs. Essential oils from the aerial parts of $T$. broussonetii showed antibacterial effects against different pathogenic bacteria such as Escherichia coli, Pseudomonas aeruginosa, Salmonella sp., Bacillus sp., Micrococcus luteus, etc. Moreover, the antifungal effects of T. broussonetii EOs against numerous pathogenic fungi, including Candida sp., Aspergillus brasiliensis, and Saccharomyces cerevisiae were reported by Jamali et al. [20] and Smahane et al. [16, 20, 26]. T. broussonetii extracts and EOs exhibited antioxidant effects using well-known techniques such as DPPH and FRAP assays $[11,13,20,25,27]$. The anticancer properties of T. broussonetii EOs have also been reported against various tumor cell lines like P815 mastocytoma, CEM, and K-562 $[12,15,21]$. Moreover, T. broussonetii was revealed to exhibit anti-inflammatory activity [28], anticorrosive potential [23], insecticidal [19, 27, 29], antiparasitic [30], antipyretic [22], antinociceptive [31], immunological, and behavioral effects [31]. In addition, the acute toxicological investigations of T. broussonetii EOs have shown death cases and some signs of toxicity [22]. However, the mechanism of action by which the bioactive compounds of T. broussonetii extracts and EOs exhibited these pharmacological effects is lacking.
Due to the intensification of research on the pharmacological effects of $T$. broussonetii and its compounds in recent years, we have reviewed all studies on this plant; botanical description, geographical distribution, chemical composition, all pharmacological effects, and the prospects of $T$. broussonetii. To the best of our knowledge, this review is the first report providing a scientific database that highlighted several aspects related to $T$. broussonetii and suggested the future potential clinical applications of this plant.

\section{Research Methodology Thymus broussonetii Boiss}

In this work, data conacring botanical description, taxonomy, destruction, phytochemistry, and pharmacological activities of $T$. broussonetii were collected using different databases (Google Scholar, Web of Science, PubMed, Scopus, ScienceDirect, SpringerLink, SciFinder, and Wiley Online). The collected data were organized in several areas and highlighted. The chemical structures of T. broussonetii were drawn using ChemDraw Pro 8.0 software.

\section{Results and Discussion}

\subsection{Botanical Description and Geographical Distribution.} Thymus broussonetii is an evergreen plant that grows to a height of around 5 centimeters. Its flowers clustered toward the top of the stems in a dense ovate-cylindrical inflorescence with floral leaves broader than the leaves, often purplecolored, attenuate-sharp at the tip, ciliated at the margins and concealing the calyces, these 2-lipped, the upper shallowly toothed; pink corolla 2-3 times the length of the calyx, with a distinctly protruding narrow tube. It differs from subsp. hannonis (Maire) Morales by the subpetiolate leaves and bracts hairy only on the inner side [1]. T. broussonetii is an endemic plant to Morocco, Tunisia, and Algeria [1]. In Morocco, it is found in the Middle Atlantic, the High Atlas, and in the north of the kingdom [32].

3.2. Chemical Composition. The secondary metabolites produced by $T$. broussonetii were the subject of numerous studies, almost all of which have been carried out on the aerial parts of this plant. The phytochemical screening of T. broussonetii extracts and EOs revealed its richness in phenolic compounds, in particular terpenoids, flavonoids, and phenolic acids. Analysis of T. broussonetii EOs by gas chromatography (GC) identified more than sixty terpenoids (Table 1; Figure 1).

The essential oil of T. broussonetii is mainly composed of spathulenol, eucalyptol, 1,8-cineole, $\beta$-caryophyllene, terpinolene, camphene, limonene, myrcene, sabinene, terpineol, terpinene, $p$-cymene, o-cymene, $\alpha$-thujene, $\alpha$-pinene, 
TABle 1: Chemical composition of T. broussonetii.

\begin{tabular}{|c|c|c|c|c|}
\hline Parts & Extracts/EOs & $\begin{array}{l}\text { Compounds } \\
\text { groups }\end{array}$ & Compounds & References \\
\hline Leaves & Essential oil & Terpenoids & $\begin{array}{l}\text { Borneol, } p \text {-cymene, carvacrol, camphene, } \alpha \text {-terpinene, } \alpha \text {-Pinene, trans- } \\
\text { sabinene hydrate, caryophyllene oxide, (E)- } \beta \text {-caryophyllene, Bornyl } \\
\text { acetate, carvacrol methyl ether, camphor, Linalool, cis-sabinene hydrate, } 4 \text { - } \\
\text { terpineol, p-cymen-8-ol, Thymol, trans-verbenol, } 1 \text {-octen-3ol, } 1,8 \text {-cineol, } \\
\quad \beta \text {-pinene }\end{array}$ & {$[11]$} \\
\hline $\begin{array}{l}\text { Flowers and } \\
\text { leaves }\end{array}$ & Essential oil & Terpenoids & $\begin{array}{l}\text { (E)- } \beta \text {-caryophyllene, } \gamma \text {-terpinene, } p \text {-cymene, carvacrol, thymol, } 4 \text { - } \\
\text { terpineol, } \beta \text {-pinene, terpendiol, borneol, caryophyllene oxide, geraniol } \\
\text { formate, p-menth-1,4(8)-diene, linalyl propionate, } \beta \text {-cadrene, thujol, } \\
\text { cinerone, } 4 \text {-isopropy-lM-2-cyclohexane-1-ol, } 1 \text {-octen-3-ol }\end{array}$ & {$[12]$} \\
\hline Aerial parts & Essential oil & Terpenoids & $\begin{array}{c}\alpha \text {-pinene, } p \text {-cymene, carvacrol, viridiflorene, borneol, } \gamma \text {-terpinene, } \\
\text { myrcene, camphene, } \alpha \text {-thujene, aromadendrene, caryophyllene oxide, } \\
\alpha \text {-terpinene, } \beta \text {-pinene, thymol, germacrene } D, \delta \text {-cadinene, linalool }\end{array}$ & {$[13]$} \\
\hline Aerial parts & Essential oil & Terpenoids & $\begin{array}{l}\text { Camphor, } \alpha \text {-terpineol, eucalyptol, germacrene } D \text {, borneol, terpinen-4-ol, } \\
\text { bicyclogermacrene, } \beta \text {-caryophyllene, } \beta \text {-bourbonene, spathulenol, } \\
\delta \text {-terpineol, bornyl acetate, caryophyllene oxide, T-muurolol, } \gamma \text {-cadinene, } \\
\text { thymol, trans-sabinene hydrate, linalool, cis-sabinne-hydrate, limonene, } p \text { - } \\
\text { cymene, dihydrocarvone, trans-carveol, } \delta \text {-cadinene, alloaromadendrene, } \\
\text { carvacrol }\end{array}$ & {$[14]$} \\
\hline \multirow[t]{2}{*}{ Leaves } & Essential oil & Terpenoids & $\begin{array}{l}\text { Carvacrol, } \mathrm{p} \text {-cymene, } \gamma \text {-terpinene, thymol, } \beta \text {--pinene, } 4 \text {-terpineol, borneol, } \\
\text { linalyl propionate, } \mathrm{p} \text {-menth-1,4(8)-diene, geraniol formate, cinerone, } \\
\text { carvacrol methyl ether, } 4 \text {-isopropyl-1M-2cyclohexane-1-ol,1-octen-3-ol }\end{array}$ & {$[15]$} \\
\hline & Essential oil & Terpenoids & $\begin{array}{c}\text { Carvacrol, p-cymene, } \alpha \text {-pinene, } \alpha \text {-terpinene, } 3 \text {-octanol, myrcene, } \\
\alpha \text {-terpineol, borneol, linalyl acetate, linalool, } \beta \text {--pinene, methyl carvacrol, } \\
\text { p-cymen-8-ol, p-mentha-1,4(8)-diene, limonene, camphene, } \gamma \text {-terpinene, } \\
\text { thymol }\end{array}$ & {$[16]$} \\
\hline Aerial parts & Essential oil & Terpenoids & $\begin{array}{l}\text { Carvacrol, thymol, } \gamma \text {-terpinene, borneol, } p \text {-cymene, } \alpha \text {-pinene, camphene, } \\
\text { myrcene, } \alpha \text {-terpinene, } \alpha \text {-thujene, limonene, } \beta \text {-pinene, linalool }\end{array}$ & {$[17]$} \\
\hline Aerial parts & Essential oil & Terpenoids & $\begin{array}{c}\text { Thymol, carvacrol, borneol, viridiflorene, spathulenol, aromadendrene, } \\
\text { camphene, } \alpha \text {-terpineol, O-cymene, terpinene- } 4 \text {-ol, } \gamma \text {-terpinene, } \\
\text { alloaromadendrene, } \gamma \text {-cadinene, } \alpha \text {-pinene, cis-dihydrocarvone, trans- } \\
\text { sabinene hydrate, } \alpha \text {-amorphene, } \beta \text {-patchoulene, } \beta \text {-cubebene, } \\
\text { isospathulenol }\end{array}$ & {$[18]$} \\
\hline Leaves & Essential oil & Terpenoids & $\begin{array}{c}p \text {-cymene, borneol, } \alpha \text {-pinene, thymol, camphene, } \gamma \text {-terpinene, carvacrol, } \\
\text { Ledene, Limonene, Myrcene, Aromadendrene, } \beta \text {-pinene, } \alpha \text {-thujene, } \alpha \text { - } \\
\text { terpinene, terpinen- } 4 \text {-ol, dihydrocarvone, allo-Aromadendrene, } \\
\beta \text {-caryophyllene, cis-sabinene hydrate, tricyclene, sabinene, } \\
\alpha \text {-phellandrene, } p \text {-Mentha-1,4(8)-diene, linalool, } \gamma \text {-muurolene, } \\
\text { spathulenol }\end{array}$ & [19] \\
\hline Aerial parts & Essential oil & Terpenoids & $\begin{array}{l}\text { Carvacrol, thymol, borneol, } \gamma \text {-terpinene, } p \text {-cymene, camphene, } \alpha \text {-pinene, } \\
\text { myrcene, viridiflorene, } \alpha \text {-terpinene, } \alpha \text {-thujene, aromadendrene, } \beta \text {-pinene, } \\
\text { limonene, caryophyllene oxide, tricyclene, } \delta \text {-cadinene, alloaromadendrene, } \\
\text { germacrene } D \text {, linalool, and limonene }\end{array}$ & {$[20]$} \\
\hline \multirow[t]{2}{*}{ Aerial parts } & Essential oil & Terpenoids & $\begin{array}{l}\text { Borneol, thymol, } p \text {-cymene, } \gamma \text {-terpinene, carvacrol, } 4 \text {-terpineol, linalyl } \\
\text { propionate, camphor, } \delta \text {-3-carene, camphene, } \beta \text {-pinene, geraniol formate, } \\
\text { p-menth-1,4(8)-diene, } \mathrm{p} \text {-mentha-1,8-diene, } 4 \text {-isopropyl-1M- } 2 \\
\text { cyclohexane-1-ol, terpinene-1-ol, carvenone, bornyl acetate, cinerone, } \\
\text { alloaromadendrene, (E)- } \beta \text {-caryophyllene, } \alpha \text {-muurolene, } \beta \text {-cedrene, } \\
\alpha \text {-cadinene, caryophyllene oxide, germacrene D }\end{array}$ & {$[21]$} \\
\hline & Essential oil & Terpenoids & $\begin{array}{c}\text { Thymol, borneol, carvacrol, } p \text {-cymene, } \delta \text { - terpinene, camphene, } \\
\text { spathulenol, myrcene, } \alpha \text {-terpineol, aromadendrene, limonene, } \beta \text {--pinene, } \\
\alpha \text {-terpinene }\end{array}$ & {$[22]$} \\
\hline Aerial parts & Essential oil & Terpenoids & $\begin{array}{c}\text { Carvacrol, o-cymene, } \gamma \text {-terpinene, } \alpha \text {-pinene, thymol, }(+) \text {-4-carene, } 4 \text { - } \\
\text { terpineol, } \alpha \text {-thujene, tau-cadinol, spathulenol, limonene, } \beta \text {-caryophyllene, } \\
\text { and camphene }\end{array}$ & [23] \\
\hline Aerial parts & Essential oil & Terpenoids & Thymol, $\alpha$-pinene, $\beta$-caryophyllene, carvacrol, $\gamma$-terpinene, borneol & {$[24]$} \\
\hline
\end{tabular}


TABLE 1: Continued.

\begin{tabular}{|c|c|c|c|c|}
\hline Parts & Extracts/EOs & $\begin{array}{l}\text { Compounds } \\
\text { groups }\end{array}$ & Compounds & References \\
\hline \multirow{8}{*}{ Leaves } & $\begin{array}{c}\text { Methanolic } \\
\text { extract }\end{array}$ & Alkaloids & - & \multirow{16}{*}[25]{} \\
\hline & Alcohol extract & Flavonoids & + & \\
\hline & $\begin{array}{c}\text { Aqueous } \\
\text { extract }\end{array}$ & Tannins & + & \\
\hline & $\begin{array}{c}\text { Ethanolic } \\
\text { extract }\end{array}$ & Coumarins & + & \\
\hline & $\begin{array}{c}\text { Methanolic } \\
\text { extract }\end{array}$ & Terpenoids & + & \\
\hline & $\begin{array}{c}\text { Petroleum } \\
\text { extract }\end{array}$ & Quinones & + & \\
\hline & & Steroids & + & \\
\hline & $\begin{array}{c}\text { Aqueous } \\
\text { extract }\end{array}$ & Carotenoids & + & \\
\hline \multirow{8}{*}{ Stems } & $\begin{array}{c}\text { Methanolic } \\
\text { extract }\end{array}$ & Alkaloids & - & \\
\hline & Alcohol extract & Flavonoids & + & \\
\hline & $\begin{array}{c}\text { Aqueous } \\
\text { extract }\end{array}$ & Tannins & + & \\
\hline & $\begin{array}{c}\text { Ethanolic } \\
\text { extract }\end{array}$ & Coumarins & + & \\
\hline & $\begin{array}{c}\text { Methanolic } \\
\text { extract }\end{array}$ & Terpenoids & + & \\
\hline & \multirow[t]{2}{*}{$\begin{array}{l}\text { Petroleum } \\
\text { extract }\end{array}$} & Quinones & + & \\
\hline & & Steroids & + & \\
\hline & $\begin{array}{l}\text { Aqueous } \\
\text { extract }\end{array}$ & Carotenoids & + & \\
\hline
\end{tabular}

camphor, bornyl acetate, borneol, thymol, linalool, and carvacrol [11-24].

Chemical variability was observed in the composition of T. broussonetii extracted by different methods. Zerrifi et al. [17] have found that T. broussonetii EOs are rich in oxygenated monoterpenes (64.5\%), monoterpene hydrocarbons (29.0\%), sesquiterpene hydrocarbons (5.8\%), and oxygenated sesquiterpenes $(0.4 \%)$, while oxygenated sesquiterpenes had the lowest percentage. The carvacrol was the main compound [17].

The same results were found by Jamali et al. [20]. For the T. broussonetii essential oil from Essaouira (Morocco), it consisted mainly of oxygenated monoterpenes (64.5\%), while the oxygenated sesquiterpenes were poorly represented $(0.4 \%)$. The main component was carvacrol $(43.4 \%)$, followed by thymol (12.3\%) [20].

Carvacrol $(39.51 \%)$ as the main constituent was also found by Chebli et al. [23]. The other components were o-cymene $(14.80 \%), \gamma$-terpinene $(10.32 \%), \alpha$-pinene $(9.7 \%)$, thymol (7.9\%), and 4-terpineol (3.22\%) [23].

In another study, camphor (46.17\%) was found to be the major component followed by $\alpha$-terpineol (7.69\%), eucalyptol (5.76), germacrene $D(5.21 \%)$, and borneol $(4.42 \%)$ of T. broussonnetii essential oil in Tamri region (Western high Atlas), Morocco [14]. In addition, linalool, $\gamma$-terpinene, cissabinene hydrate, $\beta$-caryophyllene, $p$-Menth-1,4(8)-diene, caryophyllene oxide, and carvenoneare were the main compounds identified in the essential oil of T. broussonnetii aerial parts [21].

In comparison with wild-harvested and cultivated T. broussonnetii, chromatographic analysis of their essential oil revealed the presence of 19 compounds, namely $\alpha$-pinene (5.0\%), p-cymene (5.2\%), borneol (8.5\%), $\gamma$-terpinene $(8.9 \%)$, thymol $(12.3 \%)$, and carvacrol $(43.4 \%)$ for wildharvested plants in Morocco, whereas the oil obtained from cultivated plants was characterized by a higher content of $\alpha$-pinene (6.5\%), $p$-cymene (7.2\%), and carvacrol $(60.8 \%)$ [13].

The chemical analysis of polar fraction from T. broussonnetii leaf extracts indicated the presence of flavonoids, tannins, coumarins, terpenoids, quinones, steroids, and carotenoids in the various extracts (aqueous extract, alcohol extract, and petroleum extract). Alkaloid compounds were not detected in the methanolic extract of plant leaves. In addition, flavonoids, tannins, coumarins, terpenoids, quinones, steroids, and carotenoids were the main compounds identified in the $T$. broussonnetii stem extracts [25].

\subsection{Pharmacological Properties}

3.3.1. Antibacterial Activity. Several studies have shown the antibacterial effectiveness of different essential oils from the aerial part of Thymus broussonetii [28, 39, 40, 29, 41]. Table 2 


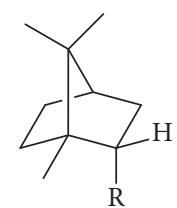

$\mathrm{R}=\mathrm{OH}:$ Borneol

$\mathrm{R}=\mathrm{O}-\mathrm{CO}-\mathrm{CH} 3$ : Bornyl acetate

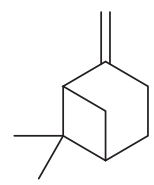

$\beta$-pinene

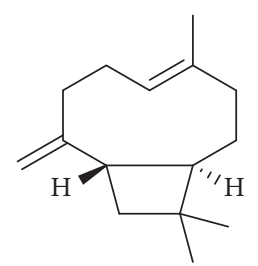

(E)- $\beta$-caryophyllene<smiles>CC(C)C1=CCC(C)(O)CC1</smiles>

Terpinene-1-ol

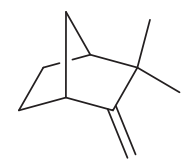

Camphene

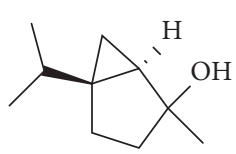

Trans-sabinene hydrate

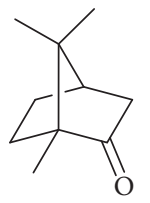

Camphor

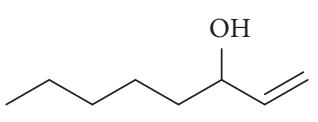

1-octen-3-ol
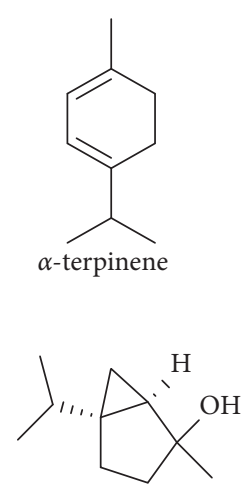

Cis-sabinene hydrate

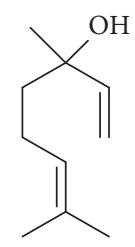

Linalool

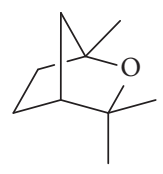

1,8-cineol<smiles>[R]C1C=C(C)C2CC1C2(C)C</smiles>

$\mathrm{R}=\mathrm{H}: \alpha$-pinene

$\mathrm{R}=\mathrm{OH}:$ Trans-verbenol

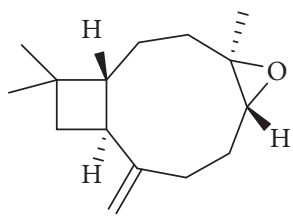

Caryophyllene oxide<smiles>CC1=CCC(O)(C(C)C)CC1</smiles>

4-Terpineol<smiles>CC1=CCC(C(C)C)=CC1</smiles>

$\gamma$-terpinene<smiles>[R]c1c(C)ccc(C([R3])(C)C)c1[R]</smiles>

$\mathrm{R}_{1}=\mathrm{H}, \mathrm{R}_{2}=\mathrm{H}, \mathrm{R}_{3}=\mathrm{H}: \mathrm{p}$-cymene

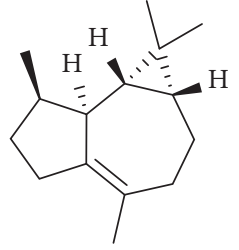

Viridiflorene

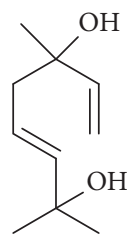

Terpendiol

$\mathrm{R}_{1}=\mathrm{H}, \mathrm{R}_{2}=\mathrm{OH}, \mathrm{R}_{3}=\mathrm{H}:$ Thymol

$\mathrm{R}_{1}=\mathrm{OH}, \mathrm{R}_{2}=\mathrm{H}, \mathrm{R}_{3}=\mathrm{H}:$ Carvacrol

$\mathrm{R}_{1}=\mathrm{OH}, \mathrm{R}_{2}=\mathrm{CH}_{3}, \mathrm{R}_{3}=\mathrm{H}:$ Methyl Carvacrol

$\mathrm{R}_{1}=\mathrm{OCH}_{3}, \mathrm{R}_{2}=\mathrm{H}, \mathrm{R}_{3}=\mathrm{H}$ : Carvacrol methyl ether

$\mathrm{R}_{1}=\mathrm{H}, \mathrm{R}_{2}=\mathrm{H}, \mathrm{R}_{3}=\mathrm{OH}$ : p-cymen-8-ol

(a)

Figure 1: Continued. 
<smiles>C=CC(=C)CCC=C(C)C</smiles>

Myrcene

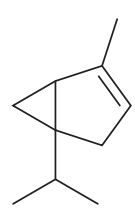

$\alpha$-Thujene

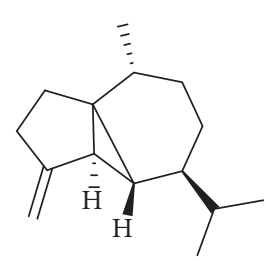

$\beta$-cubebene

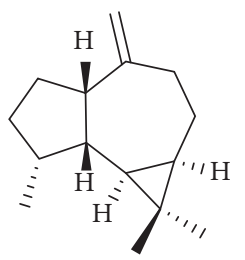

Alloaromadendrene<smiles>CC1=CC2C(C)=CCC(C(C)C)C2CC1</smiles>

$\alpha$-amorphene<smiles>C[C@@H]1CC2=C(C[C@@H](C)[C@H]2C)[C@@H]1C</smiles>

$\beta$-patchoulene<smiles>CC1=CCC(=C(C)C)CC1</smiles>

p-menth-1,4(8)-diene<smiles>CC1C(=O)CC2(C(C)C)CC1C2</smiles>

Thujol

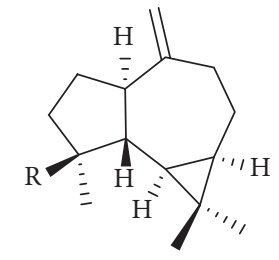

$\mathrm{R}=\mathrm{H}:$ Aromadendrene

$\mathrm{R}=\mathrm{OH}:$ Spathulenol

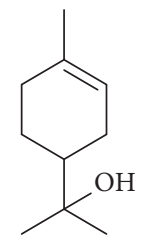

$\alpha$-Terpineol<smiles>CC1=CCCC2C(C=C(C)CCC1)C2(C)C</smiles>

Bicyclogermacrene<smiles>C=C1CC[C@H](C(C)C)[C@H]2C=C(C)CC[C@@H]12</smiles>

$\gamma$-Cadinene<smiles>[R]CC(=O)OC(C)(C=C)CCC=C(C)C</smiles>

$\mathrm{R}=\mathrm{H}$ : Linalyl acetate $\mathrm{R}=\mathrm{CH} 3$ : Linalyl propionate

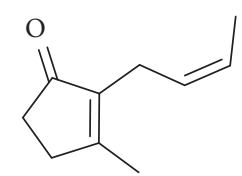

Cinerone<smiles>C=C(C)[C@@H]1C/C=C(/C)CC/C=C(\C)CC1</smiles>

Germacrene D<smiles>C=C1CCC(C(C)(C)O)CC1</smiles>

$\delta$-Terpineol

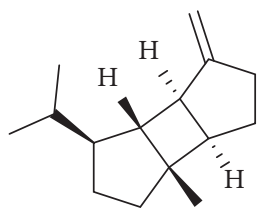

$\beta$-Bourbonene<smiles>[R]C1CC(C(=C)C)CC=C1C</smiles>

$\mathrm{R}=\mathrm{H}:$ Limonene $\mathrm{R}=\mathrm{OH}:$ trans-Carveol

(b)

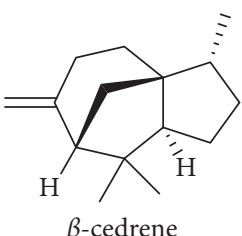<smiles>CC(C)C1C=CC(C)(O)CC1</smiles>

4-isopropyl-1-methyl-2-cyclohexane-1-ol<smiles>CC1=CC2C(C)=CCCC2C(C)C1</smiles>

$\delta$-Cadinene

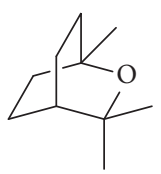

Eucalyptol<smiles>CC1=C[C@@H]2[C@H](CC1)[C@@H](O)CC[C@@H]2C(C)C</smiles>

T-Muurolol<smiles>C=C(C)C1CCC(C)C(=O)C1</smiles>

Dihydrocarvone

Figure 1: Continued. 
<smiles>CC1=C2CCC(C)(O)C2C2C(CC1)C2(C)C</smiles>
Isospathulenol<smiles>C=C1CCC(C(C)C)C2C=C(C)CCC12</smiles>

$\gamma$-muurolene<smiles>CC1=C[C@H]2CCC(C)=C[C@H]2[C@@H](O)CC1</smiles>

Tau-Cadinol<smiles>C=C(C)C1CC=C(C)CC1</smiles>

p-Mentha-1,8-diene<smiles>CCCCCC(O)CC</smiles>

3-octanol

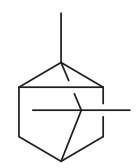

Tricyclene<smiles>CC1=C[C@H]2C(C)=CC[C@H](C(C)C)[C@H]2CC1</smiles>

$\alpha$-Cadinene<smiles>CC(C)C1=CC(=O)C(C)CC1</smiles>

Carvenone<smiles>Cc1ccccc1C(C)C</smiles>

o-Cymene

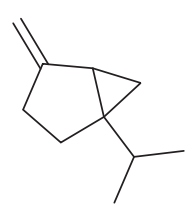

Sabinene<smiles>CC1=CC2C(C)=CCC(C(C)C)C2CC1</smiles>

$\alpha$-muurolene

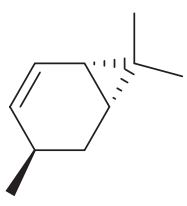

(+)-4-Carene<smiles>C=C(C)[C@H]1CC[C@@H](C)C(=O)C1</smiles>

Cis-Dihydrocarvone<smiles>CC1=CCC(C(C)C)C=C1</smiles>

$\alpha$-phellandrene<smiles>CC1=CCC2C(C1)C2(C)C</smiles>

$\delta$-3-Carene<smiles>C=C(C)c1ccccc1C</smiles>

Benzene,1-methyl-2-(1-methylethyl)<smiles>CC(C)=CCC/C(C)=C/COC=O</smiles>

(c)

Figure 1: Chemical composition of T. Thymus broussonetii.

summarizes all the studies which evaluated this activity in Thymus broussonetii, including the plant part used, type of extract, the antibacterial test, the strains studied, and the key results. The literature screening indicated that scientists had investigated the effect of Thymus broussonetii against the most critical pathogenic agents belonging to Gram-negative and Gram-positive bacteria. Indeed, Lattaoui and Tantaoui-elaraki, [34] assessed the antibacterial activity of the essential oil of $T$. broussonetii aerial part against three bacteria (Staphylococcus aureus, Escherichia coli, and Bacillus megaterium). The result of this study showed that T. broussonetii essential oils inhibited the growth of all bacterial strains with MIC values of 1,3 , and $4 \%(\mathrm{v} / \mathrm{v})$ against $S$. aureus, E. coli, and $B$. megaterium, respectively. Belaqziz et al. [33] reported the antibacterial activity of $T$. broussonetti leaf EOs using agar disc diffusion against two Gram-positive bacteria, including S. aureus and Bacillus subtilis, and four Gram-negative bacteria, namely E. coli, Salmonella sp, Vibrio cholerae, and Pseudomonas aeruginosa. The results showed that the essential oil exhibited promising antibacterial power against the strains tested; Bacillus subtilis $(\Phi=33 \pm 0.4 \mathrm{~mm})$, S. aureus $(\Phi=19 \pm 0.8 \mathrm{~mm})$, Salmonella sp. $(\Phi=9 \pm 0.9 \mathrm{~mm})$, Escherichia coli $(\Phi=21 \pm 0.1 \mathrm{~mm})$, Vibrio cholerae $(\Phi=40 \pm 0.4 \mathrm{~mm})$ and $P$. aeruginosa $(\Phi=9 \pm 0.1 \mathrm{~mm})$. In another study, El Bouzidi et al. [13] tested the antibacterial activity of essential oils obtained from both wild and cultivated T. broussonetii using agar disc diffusion and macrodilution methods against Salmonella sp. (CCMM B17), E. coli (CCMM B4), E. coli (ATCC 25922), Bacillus cereus (ATCC 14579), Bacillus subtilis (ATCC 9524), Micrococcus luteus 
TABLE 2: Antibacterial effects of T. broussonetii.

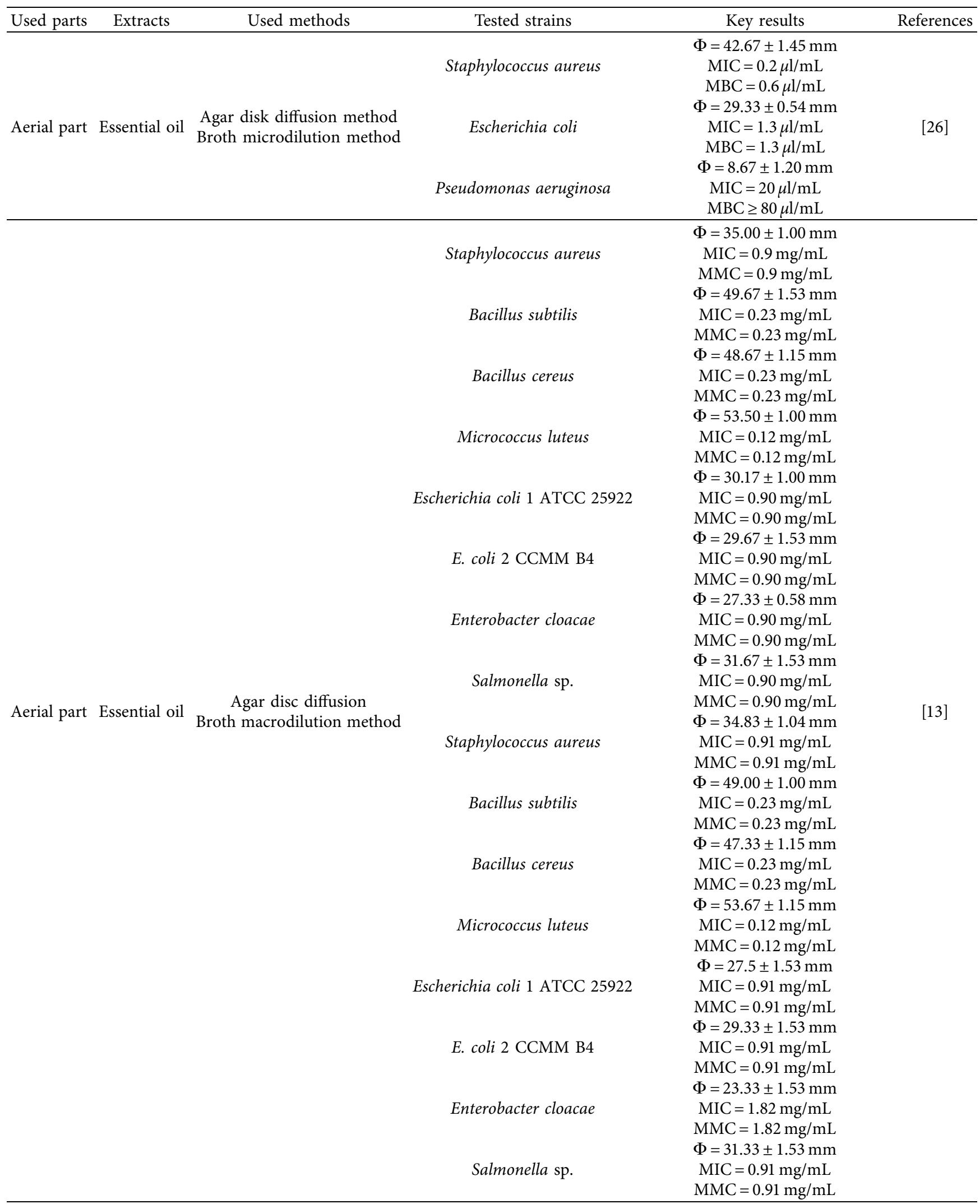


TABLE 2: Continued.

\begin{tabular}{|c|c|c|c|c|c|}
\hline Used parts & Extracts & Used methods & Tested strains & Key results & References \\
\hline Aerial part & Essential oil & Agar diffusion method & $\begin{array}{c}\text { Bacillus subtilis } \\
\text { Staphylococcus aureus } \\
\text { Salmonella sp. } \\
\text { Escherichia coli } \\
\text { Vibrio cholerae } \\
\text { Pseudomonas aeruginosa }\end{array}$ & $\begin{array}{c}\Phi=33 \pm 0.4 \mathrm{~mm} \\
\Phi=19 \pm 0.8 \mathrm{~mm} \\
\Phi=19 \pm 0.9 \mathrm{~mm} \\
\Phi=21 \pm 0.1 \mathrm{~mm} \\
\Phi=40 \pm 0.4 \mathrm{~mm} \\
\Phi=9 \pm 0.1 \mathrm{~mm}\end{array}$ & {$[33]$} \\
\hline Aerial part & Essential oil & Disc diffusion method & Microcystis aeruginosa & $\begin{array}{c}\Phi=90 \pm 0.00 \mathrm{~mm} \\
\mathrm{MIC}=0.047 \mathrm{mg} / \mathrm{mL} \\
\mathrm{MBC}=0.095 \mathrm{mg} / \mathrm{ml}\end{array}$ & {$[17]$} \\
\hline Aerial part & Essential oil & Agar diffusion method & Staphylococcus aureus & No measurable zone of inhibition & {$[34]$} \\
\hline Aerial part & Essential oil & Agar diffusion method & $\begin{array}{c}\text { Escherichia coli } \\
\text { Staphylococcus aureus } \\
\text { Bacillus megaterium }\end{array}$ & $\begin{array}{l}\text { No measurable zone of inhibition } \\
\qquad \begin{array}{c}\text { MIC }=1 \% \\
M I C=3 \% \\
M I C=4 \%\end{array}\end{array}$ & [16] \\
\hline
\end{tabular}

(ATCC10240), S. aureus (CCMM B3), and the clinically isolated strain, Enterobacter cloacae. Both EOs obtained from $T$. broussonetii (wild and cultivated) exhibited inhibitory activity on all the selected microorganisms, with inhibitory zones ranging between 23.33 and $53.67 \mathrm{~mm}$ and MIC values varied from 0.12 to $1.82 \mathrm{mg} / \mathrm{mL}$. In fact, Micrococcus luteus was the most sensitive strain with MIC values of 53.50 and $53.67 \mathrm{mg} / \mathrm{mL}$ for wild and cultivated $T$. broussonetii, respectively, followed by B. subtilis, B. cereus, and $S$. aureus. However, Smahane et al. [26] investigated the inhibitory effect of $T$. broussonetii aerial part EOs against $S$. aureus, E. coli, and $P$. aeruginosa using disk diffusion and broth microdilution methods. The results revealed that all microorganisms tested were inhibited by essential oils with inhibitory zones ranging between 8.67 and $42.67 \mathrm{~mm}$ and MIC values ranged between 0.2 and $20 \mu \mathrm{g} / \mathrm{mL}$.

Recently, Zerrifi and collaborators determined the in vitro antibacterial activity of $T$. broussonetii aerial part EOs using paper disk diffusion and microdilution methods against Microcystis aeruginosa. According to this study, the essential oils exhibited promising antibacterial power against the strain tested with an inhibitory zone of $90 \mathrm{~mm}$, and MIC and MBC values of 0.047 and $0.095 \mathrm{mg} / \mathrm{mL}$, respectively [17].

3.3.2. Antifungal Activity. The antifungal activity of T. broussonetii EOs against many fungal strains was reported in several works $[13,16,18,20,26,34]$. The previous publications on the antifungal activity that studied the essential oils from aerial parts of $T$. broussonetii by different methods are summarized in Table 3.

Saad et al. [18] determined the in vitro antifungal efficacy of the essential oil from the aerial part against Candida albicans using the agar diffusion and macrodilution broth methods. Consequently, the zones of inhibition and MIC value were $38.5 \mathrm{~mm}$ and $0.25 \mu \mathrm{g} / \mathrm{mL}$, respectively. Moreover, Jamali et al. [20] evaluated the EOs from aerial parts of the studied plant for their antifungal action against Candida albicans, Candida krusei, Candida glabrata, and Candida parapsilosis using agar disc diffusion and microdilution methods. The results revealed a strong antifungal activity against all the fungi tested with zones of inhibition ranging from 49.33 to $51.17 \mathrm{~mm}$ and MIC value of $0.45 \mathrm{mg} / \mathrm{mL}$. Using the same methods and the same fungal strains, El Bouzidi et al. [13] investigated the antifungal activity of EOs obtained from wild and cultivated $T$. broussonetii. Therefore, these oils inhibited the growth of all fungal species with MIC values of 0.45 and $0.45 \mathrm{mg} / \mathrm{mL}$ for wild and cultivated Thymus broussonetii, respectively. In another study, the essential oil of T. broussonetii was tested against two fungal strains (Candida albicans and Aspergillus brasiliensis). The results revealed a strong antifungal inhibition against Candida albicans with zones of inhi-

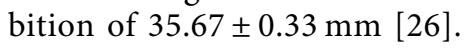

3.3.3. Antioxidant Activity. Different studies have evaluated the antioxidant activity of extracts and EOs from different parts of $T$. broussonetii using well-known techniques such as DPPH and FRAP assays [11, 13, 20, 25, 27] (Table 4). Indeed, Jamali et al. [20] investigated the antioxidant activity of the essential oils from aerial parts of $T$. broussonetii, and the results showed that the essential oil exhibited an interesting anti-DPPH $\left(\mathrm{IC}_{50}=97.48 \pm 2.24 \mu \mathrm{g} / \mathrm{mL}\right)$ and a high reducing power $\left(\mathrm{EC}_{50}=167.86 \pm 1.46 \mu \mathrm{g} / \mathrm{ml}\right)$ compared with the standard antioxidants, quercetin, and $\mathrm{BHT}$ with $\mathrm{IC}_{50}$ values of $1.07 \pm 0.01$ and $4.21 \pm 0.08 \mu \mathrm{g} / \mathrm{mL}$, respectively, for $\mathrm{DPPH}$ and with $\mathrm{EC}_{50}$ values of $2.29 \pm 0.1$ and $7.09 \pm 0.1 \mu \mathrm{g} / \mathrm{mL}$, respectively, for FRAP. In another study, the wild and cultivated T. broussonetii EOs were tested for their antioxidant activity by DPPH and ferric ion reduction assays. The results showed an interesting antioxidant effect of the wild and cultivated T. broussonetii EOs with $\mathrm{IC}_{50}$ values of $132.23 \pm 3.09$ and $145.83 \pm 3.47 \mu \mathrm{g} / \mathrm{mL}$, respectively, for DPPH and with $\mathrm{EC}_{50}$ values of $167.87 \pm 1.46$ and $169.355 \pm 2.04 \mu \mathrm{g} / \mathrm{mL}$, respectively, for FRAP [13]. Moreover, Ouariachi et al. [11] demonstrated that the essential oils from $T$. broussonetii possessed high antioxidant activity using DPPH $\left(\mathrm{IC}_{50}=90 \mu \mathrm{g} / \mathrm{mL}\right)$. On the other hand, Ahlam et al. [25] reported the antioxidant activity of the aqueous and methanol extracts from leaves and stems of T. broussonetii using FRAP and DPPH methods. The results revealed that both extracts exhibited a good antioxidant activity with FRAP capacity values 
TABle 3: Antifungal activity of T. broussonetii.

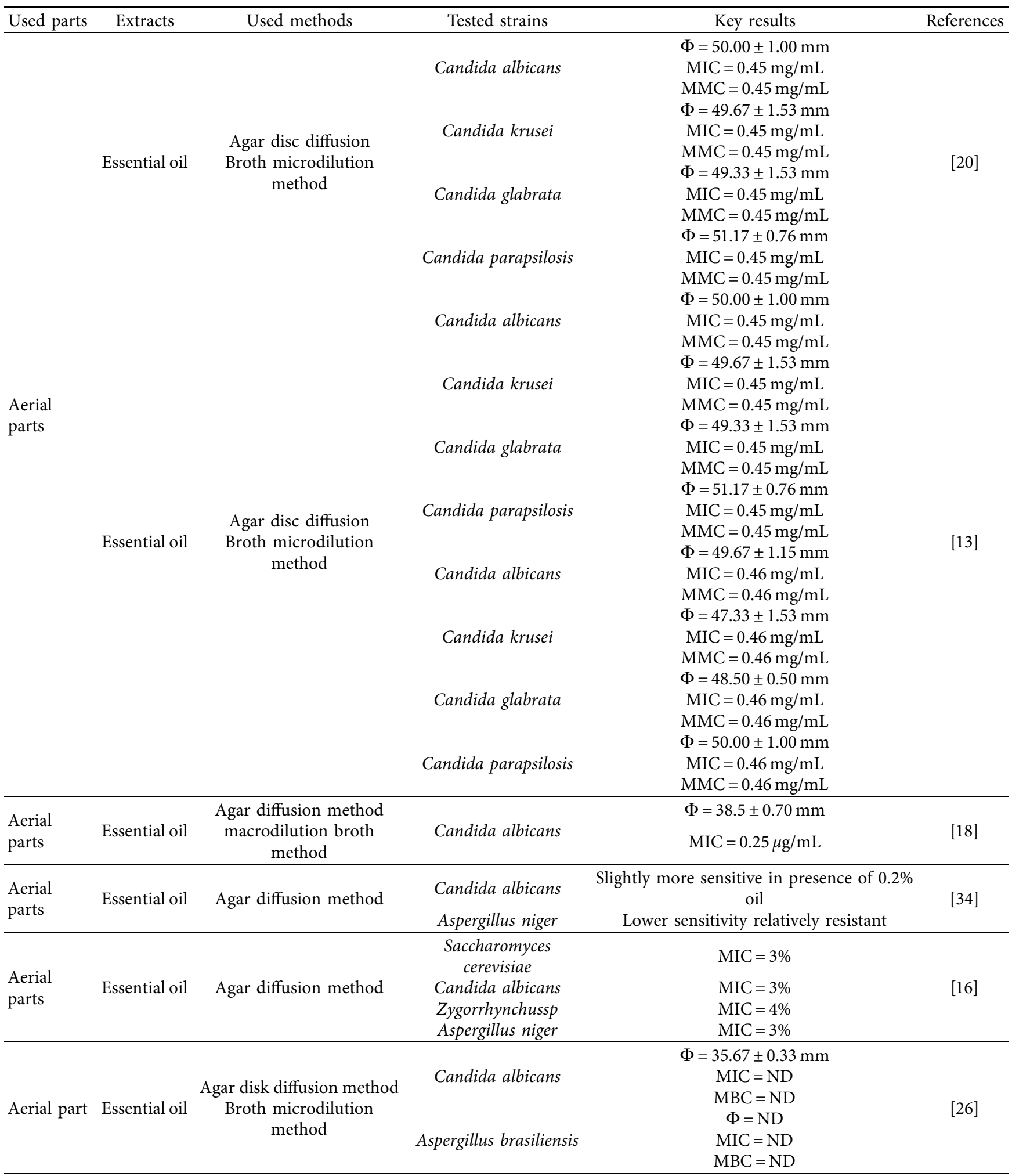

ranging between $0.105 \pm 0.021$ and $1.579 \pm 0.014 \mathrm{mg} / \mathrm{mL}$ and anti-DPPH power with $\mathrm{IC}_{50}$ values ranging between $0.132 \pm 0.034$ and $7.665 \pm 0.411 \mathrm{mg} / \mathrm{mL}$. The highest activity was observed in methanol extract from stems with $\mathrm{EC}_{50}$ and $\mathrm{IC}_{50}$ values of $0.105 \pm 0.021$ and $0.132 \pm 0.034 \mathrm{mg} / \mathrm{mL}$, respectively. On the other hand, essential oil showed a
DPPH-radical-scavenging activity with $\mathrm{IC}_{50}=13.24 \pm$ $0.06 \mathrm{mg} / \mathrm{mL}$ [27].

3.3.4. Anticancer Activity. The anticancer properties of $T$. broussonetii have also been studied. Indeed, some investigations tested the efficiency of $T$. broussonetii essential oils 
TABLE 4: Antioxidant effects of T. broussonetii.

\begin{tabular}{|c|c|c|c|c|}
\hline Used parts & Extracts & Used methods & Key results & References \\
\hline \multirow{2}{*}{ Leaves } & Aqueous extract & \multirow{4}{*}{ DPPH } & $\mathrm{IC}_{50}=22.61 \pm 1.022 \mathrm{mg} / \mathrm{mL}$ & \multirow{8}{*}[25]{} \\
\hline & Methanol extract & & $\mathrm{IC}_{50}=6.484 \pm 0.190 \mathrm{mg} / \mathrm{mL}$ & \\
\hline \multirow{2}{*}{ Stems } & Aqueous extract & & $\mathrm{IC}_{50}=7.665 \pm 0.411 \mathrm{mg} / \mathrm{mL}$ & \\
\hline & Methanol extract & & $\mathrm{IC}_{50}=0.132 \pm 0.034 \mathrm{mg} / \mathrm{mL}$ & \\
\hline \multirow{2}{*}{ Leaves } & Aqueous extract & \multirow{4}{*}{ FRAP } & $\mathrm{EC}_{50}=0.597 \pm 0.013 \mathrm{mg} / \mathrm{mL}$ & \\
\hline & Methanol extract & & $\mathrm{EC}_{50}=1.579 \pm 0.014 \mathrm{mg} / \mathrm{mL}$ & \\
\hline \multirow{2}{*}{ Stems } & Aqueous extract & & $\mathrm{EC}_{50}=0.489 \pm 0.011 \mathrm{mg} / \mathrm{mL}$ & \\
\hline & Methanol extract & & $\mathrm{EC}_{50}=0.105 \pm 0.021 \mathrm{mg} / \mathrm{mL}$ & \\
\hline Aerial parts & Essential oil & DPPH & $\mathrm{IC}_{50}=13.24 \pm 0.06 \mathrm{mg} / \mathrm{mL}$ & {$[27]$} \\
\hline Aerial parts & Essential oil & DPPH & $\mathrm{IC}_{50}=90 \mu \mathrm{g} / \mathrm{mL}$ & [11] \\
\hline \multirow{2}{*}{ Aerial parts (wild) } & \multirow{2}{*}{ Essential oil } & $\mathrm{DPPH}$ & $\mathrm{IC}_{50}=132.23 \pm 3.09 \mu \mathrm{g} / \mathrm{mL}$ & \multirow{4}{*}[13]{} \\
\hline & & FRAP & $\mathrm{EC}_{50}=167.87 \pm 1.46 \mu \mathrm{g} / \mathrm{mL}$ & \\
\hline \multirow{2}{*}{ Aerial parts (cultivated) } & \multirow{2}{*}{ Essential oil } & $\mathrm{DPPH}$ & $\mathrm{IC}_{50}=145.83 \pm 3.47 \mu \mathrm{g} / \mathrm{mL}$ & \\
\hline & & FRAP & $\mathrm{EC}_{50}=169.355 \pm 2.04 \mu \mathrm{g} / \mathrm{mL}$ & \\
\hline Aerial parts (wild) & Essential oil & DPPH & $\mathrm{IC}_{50}=97.48 \pm 2.24 \mu \mathrm{g} / \mathrm{mL}$ & \multirow{2}{*}[20]{} \\
\hline Aerial parts (wild) & Essential oil & FRAP & $\mathrm{EC}_{50}=167.86 \pm 1.46 \mu \mathrm{g} / \mathrm{mL}$ & \\
\hline
\end{tabular}

on many cell lines [12, 15, 21] (Table 5). Ait M'Barek et al. [15] evaluated the antiproliferative effect of $T$. broussonetii EOs from stem and leaves on human ovarian adenocarcinoma IGR-OV1 parental cell line OV1/P. The results showed that the EOs tested inhibited the proliferation of this adenocarcinoma with an $\mathrm{IC}_{50}$ value of $0.40 \pm 0.02(\% \mathrm{v} / \mathrm{v})$.

Moreover, Thymus broussonetii EOs extracted from flowers and leaves have been tested by Jaafari et al. [21] on the P815 mastocytoma cell line using MTT assay. In this study, the essential oils exhibited an important dose-dependent cytotoxic effect against the P815 cell line $\left(\mathrm{IC}_{50}=0.016 \%\right)$.

In another study, the authors evaluated the cytotoxic activity of essential oils from two chemotypes of T. broussonetii against five tumor cell lines, namely P-815 (murine mastocytoma), K-562 (human chronic myelogenous leukemia), CEM (acuteT lymphoblastoid leukemia), and MCF 7 (human breast adenocarcinoma) and its counterpart resistant to gemcitabine (MCF -7 gem) using MTT assay. Consequently, cell viability showed a cell proliferation inhibition by the tested products in a dose-dependent manner with $\mathrm{IC}_{50}$ values ranging between 3.1 and $17.5 \%(\mathrm{v} / \mathrm{v})$. Additionally, cell cycle analysis detected cell cycle arrest at $S$ and G0/G1 phases in cells. This considerable activity might be due to the high content of thymol and carvacrol known for their promising anticancer effects via numerous mechanisms of action such as angiogenesis, inhibition of cell migration, autophagy, apoptosis, and cell cycle arrest $[35,36]$.

3.3.5. Anti-Inflammatory Activity. The antiedema effects of hexane, chloroform, and methanol extracts of T. broussonettii were evaluated on croton oil-induced ear edema in mice. The chloroform extract showed the highest activity, reducing the oedematous response by $47 \%$, the $\mathrm{ID}_{50}$ value of the indomethacin used as the reference $\operatorname{drug}\left(286 \mathrm{~g} / \mathrm{cm}^{2}\right)$ is three times higher than that of the chloroform extract $93 \mathrm{~g} / \mathrm{cm}^{2}$. The chloroform extract of $T$. broussonettii possesses an anti-inflammatory activity ascribable to its triterpenic acid content; in fact, ursolic and oleanolic acid justify the edema inhibition observed. Ursolic acid was more potent than oleanolic acid with ID $_{50}$ values of 56 and $132 \mathrm{~g} / \mathrm{cm}^{2}$ corresponding to 0.12 and $0.29 \mathrm{~mol} / \mathrm{cm}^{2}$, respectively [28] (Table 6).

3.3.6. Anticorrosive Potential. The essential oils of $T$. broussonnetii at different concentrations (ranging from 0.05 to $2 \mathrm{~g} / \mathrm{L}$ ) were tested against corrosion on C38 steel in $1 \mathrm{M}$ medium, $\mathrm{HCl}$, using electrochemical impedance spectroscopy (EIS), potentiodynamic polarization, and weight loss methods. The essential oil was found to be rich in bioactive substances, mainly carvacrol (39.51\%) followed by benzene, 1methyl-2-(1-methylethyl) (14.80\%), gammaterpinene (10.32\%), alpha-pinene (9.7\%), thymol (7.9\%), and 3-cyclohexen-1-ol, 4-methyl-1-(1-methylethyl) (3.22\%). Using the EIS test, the essential oil $(2 \mathrm{~g} / \mathrm{L})$ inhibited the corrosion of metals and alloys in acid solutions with a percentage of $82.35 \%$ of the inhibition efficiency. The polarization studies showed that T. broussonnetii EOs inhibit both anodic metal dissolution and cathodic hydrogen reduction reactions. At the highest inhibition concentration, the maximum inhibition efficiency observed indicates that many molecules were adsorbed on the metal surface. At $2 \mathrm{~g} / \mathrm{L}$, the best efficiency obtained in the presence of essential oil was $81.63 \%$. It has been noted that the inhibition efficiency increases with increasing temperature. The highest efficiency was $90 \%$ and reached $328 \mathrm{~K}$. The inhibitory mechanism was probably achieved by chemical adsorption (chemisorption) of TBS molecules on the surface of carbon steel and this indeed increases with rising temperature [23] (Table 6).

3.3.7. Insecticidal Activities. The T. broussonetti EOs were investigated for their insecticidal activity, using the larvae test sensibility technique. The chemical analysis by GCMS showed that the major compounds of $T$. broussonetii essential oil were p-cymene $(21.0 \%)$, borneol $(16.5 \%)$, $\alpha$-pinene $(11.8 \%)$, and thymol $(11.3 \%)$. The EOs of this plant proved larvicidal effectiveness against the fourth instar larvae of Culex pipiens and were significantly higher at the dose of $0.125 \mathrm{ppm}$ compared to the control. The lethal concentration $50\left(\mathrm{LC}_{50}\right)$ during 
Table 5: Anticancer effects of T. broussonetii.

\begin{tabular}{|c|c|c|c|c|c|}
\hline Parts used & Extracts & $\begin{array}{l}\text { Used } \\
\text { methods }\end{array}$ & Cell lines & Key results & References \\
\hline $\begin{array}{l}\text { Leaves and } \\
\text { stems }\end{array}$ & Essential oils & $\begin{array}{l}\text { Crystal violet } \\
\text { assay }\end{array}$ & $\begin{array}{l}\text { The parental human ovarian adenocarcinoma } \\
\text { cell line IGR-OV1 (OV1/P) }\end{array}$ & $\begin{array}{c}\mathrm{IC}_{50}=0.40 \pm 0.02 \%(\mathrm{v} / \\
\mathrm{v})\end{array}$ & {$[15]$} \\
\hline \multirow{3}{*}{$\begin{array}{l}\text { Flowers and } \\
\text { leaves }\end{array}$} & \multirow[t]{2}{*}{$\begin{array}{l}\text { Essential oils } \\
\text { (variety: TbA) }\end{array}$} & \multirow[t]{2}{*}{ MTT assay } & $\begin{array}{c}\text { P815 mastocytoma cell line } \\
\text { CEM } \\
\text { K-562 } \\
\text { MCF }-7\end{array}$ & $\begin{aligned} \mathrm{IC}_{50} & =4.7 \%(\mathrm{v} / \mathrm{v}) \\
\mathrm{IC}_{50} & =3.6 \%(\mathrm{v} / \mathrm{v}) \\
\mathrm{IC}_{50} & =10 \%(\mathrm{v} / \mathrm{v}) \\
\mathrm{IC}_{50} & =10 \%(\mathrm{v} / \mathrm{v})\end{aligned}$ & \multirow{3}{*}[12]{} \\
\hline & & & MCF -7 gem & $\mathrm{IC}_{50}=8.9 \%(\mathrm{v} / \mathrm{v})$ & \\
\hline & $\begin{array}{l}\text { Essential oils } \\
\text { (variety: TbB) }\end{array}$ & MTT assay & $\begin{array}{c}\text { P815 mastocytoma cell line } \\
\text { CEM } \\
\text { K-562 } \\
\text { MCF -7 } \\
\text { MCF -7 gem }\end{array}$ & $\begin{array}{l}\mathrm{IC}_{50}=8.5 \%(\mathrm{v} / \mathrm{v}) \\
\mathrm{IC}_{50}=3.1 \%(\mathrm{v} / \mathrm{v}) \\
\mathrm{IC}_{50}=13.5 \%(\mathrm{v} / \mathrm{v}) \\
\mathrm{IC}_{50}=15.4 \%(\mathrm{v} / \mathrm{v}) \\
\mathrm{IC}_{50}=17.5 \%(\mathrm{v} / \mathrm{v})\end{array}$ & \\
\hline $\begin{array}{l}\text { Flowers and } \\
\text { leaves }\end{array}$ & Essential oils & MTT assay & P815 mastocytoma cell line & $\mathrm{IC}_{50}=0.016 \%(\mathrm{v} / \mathrm{v})$ & {$[21]$} \\
\hline
\end{tabular}

TABLE 6: Other pharmacological activities of T. broussonetii.

\begin{tabular}{|c|c|c|c|c|c|}
\hline Activities & $\begin{array}{l}\text { Used } \\
\text { parts }\end{array}$ & Extracts & Experimental approaches & Key results & References \\
\hline $\begin{array}{l}\text { Anti-inflammatory } \\
\text { activity }\end{array}$ & Leaves & $\begin{array}{c}\text { n-hexane } \\
\text { Chloroform } \\
\text { Chloroform + methanol } \\
\text { Methanol }\end{array}$ & $\begin{array}{l}\text { Croton oil ear test in mice } \\
\text { inhibition of the croton oil- } \\
\text { induced ear edema in mice }\end{array}$ & $\begin{array}{c}\text { Edema reduction }=9 \% \\
\text { Edema reduction }=47 \% \\
\text { Edema reduction }=16 \% \\
\text { Edema reduction }=-5 \%\end{array}$ & {$[28]$} \\
\hline Anticorrosive activity & $\begin{array}{c}\text { Aerial } \\
\text { parts }\end{array}$ & Essential oils & $\begin{array}{l}\text { Loss measurements and } \\
\text { electrochemical techniques }\end{array}$ & $\begin{array}{c}82.35 \% \text { inhibition efficiency } \\
\text { at a dose of } 2 \mathrm{~g} / \mathrm{L}\end{array}$ & {$[23]$} \\
\hline Insecticidal activity & $\begin{array}{l}\text { Aerial } \\
\text { parts }\end{array}$ & Essential oils & $\begin{array}{c}\text { Fourth instar larvae of Culex } \\
\text { pipiens }\end{array}$ & $\mathrm{LC}_{50}=0.23$ & [19] \\
\hline Antiparasitic activity & $\begin{array}{c}\text { Aerial } \\
\text { parts }\end{array}$ & Essential oils & $\begin{array}{l}\text { Oral administration }(20 \mathrm{~g} / \\
\text { animal }) \text { at the time of infection } \\
\text { and thereafter for several days }\end{array}$ & $\begin{array}{c}\text { Absence of intracerebral } \\
\text { cysts } \\
\text { No anomalies }\end{array}$ & {$[30]$} \\
\hline Antipyretic activity & Stem & $\begin{array}{l}\text { Water, butanol, and ethyl } \\
\text { acetate }\end{array}$ & Yeast-induced fever in rats & $\begin{array}{l}\text { Significantly reduced the } \\
\text { temperature in febrile rats }\end{array}$ & {$[37]$} \\
\hline Acute toxicity & $\begin{array}{c}\text { Aerial } \\
\text { parts }\end{array}$ & Essential oils & Swiss mice $(25-35 \mathrm{~g})$ & $\mathrm{LD}_{50}=2.66 \mathrm{~g} / \mathrm{kg}$ & {$[22]$} \\
\hline $\begin{array}{l}\text { Antinociceptive } \\
\text { activity }\end{array}$ & $\begin{array}{l}\text { Leaves } \\
\text { and stem }\end{array}$ & $\begin{array}{l}\text { Water } \\
\text { Ethyl acetate and butanol }\end{array}$ & $\begin{array}{l}\text { Chemical and thermal models } \\
\text { (in vivo) }\end{array}$ & $\begin{array}{l}\text { Writhing inhibition }=88.9 \% \\
\text { Writhing inhibition }=69 \% \\
\text { Writhing inhibition }=62.8 \%\end{array}$ & {$[31]$} \\
\hline Insecticidal activity & $\begin{array}{c}\text { Aerial } \\
\text { parts }\end{array}$ & Essential oils & $\begin{array}{l}\text { Effect against adults of Tribolium } \\
\text { castaneum herbst }\end{array}$ & $\begin{array}{l}\mathrm{LD}_{50}=0.08 \mu \mathrm{l} / \mathrm{cm}^{2} \\
\mathrm{LD}_{90}=0.19 \mu \mathrm{l} / \mathrm{cm}^{2}\end{array}$ & {$[29]$} \\
\hline Insecticidal activity & $\begin{array}{l}\text { Aerial } \\
\text { parts }\end{array}$ & Essential oils & $\begin{array}{l}\text { Effect against Tribolium } \\
\text { castanum pest foodstuffs }\end{array}$ & $\mathrm{TL}_{50}=1.5 \mu \mathrm{l} / \mathrm{cm}^{2}$ & {$[27]$} \\
\hline $\begin{array}{l}\text { Immunological and } \\
\text { behavioral activities }\end{array}$ & $\begin{array}{l}\text { Leaves } \\
\text { and stem }\end{array}$ & $\begin{array}{l}\text { Water, butanol, and ethyl } \\
\text { acetate }\end{array}$ & $\begin{array}{l}\text { Tested the neurostimulant } \\
\text { effects of the extracts }\end{array}$ & $\begin{array}{l}\text { Increased (in vivo) the } \\
\text { number of leukocyte } \\
\text { categories studied }\end{array}$ & {$[31]$} \\
\hline
\end{tabular}

exposure of the insect population to EOs at 24 hours was 0.23 , and the effective toxicity on $C$. pipiens larvae was associated with the thymol compound of thyme oil [19] (Table 6).

3.3.8. Antipyretic Activity. At a dose of $200 \mathrm{mg} / \mathrm{kg}$ b.w., T. broussonetii aqueous, butanol, and ethyl acetate extracts were investigated in vivo for their antipyretic effect on yeastinduced fever. In normothermic rats, the extracts were tested to determine whether the antipyretic activity is related to a hypothermic effect. Indeed, all extracts significantly reduced rectal temperature in febrile animals. However, they did not induce hypothermia in normal rats. Besides, an inhibition of platelet aggregation has been observed by acting in the same way as NSAI drugs. Furthermore, extracts of T. broussonetii contain many types of compounds such as triterpenes, saponins, tannins, flavonoids, and several salicylates. The presence of these compounds can enhance this antipyretic activity [22] (Table 6).

3.3.9. Antinociceptive. The immunostimulatory and neurotropic antistress effects of extracts (aqueous, ethyl acetate, and butanolic extracts) and EOs of T. broussonetii were evaluated at three doses. Therefore, the aqueous and ethyl 
acetate extracts showed the best results. In fact, thyme extracts increased the number of leucocyte categories studied, in particular polynuclear cells, total lymphocytes, TCD4+, TCD8+, and NK cells. It has been suggested that intraperitoneal administration of $T$. broussonetii extracts has a potent direct effect on leucocytes in vivo. In contrast, this assumes that the two extracts partially prevent stress-induced disturbances in the rate of leukocytes. The ethyl acetate extract inhibited the increase in polynuclear cells caused by stress, increased lymphocytes, and decreased polynuclear counts in the stressed mice treated with the aqueous extract compared to the stressed mice [31].

$T$. broussonetii was investigated to study the behavioral effects using the light/dark box test. At $12 \mathrm{mg} / \mathrm{kg}$, the aqueous extract increased the number of transitions and the number of traversed squares and decreased the time spent in the dark compartment. The ethyl acetate extract increased both the number of traversed squares and the number of transitions without affecting the time spent in the dark compartment. The aqueous extract exerted an anxiolytic effect on the animals, while it could rather enhance locomotor and exploratory activities. The improvement in animal activity observed in the light/dark box after treatment with the aqueous extract is rather due to its anxiolytic-like effect and the ethyl acetate extract improved exploratory and locomotor activities in mice (Table 6).

3.3.10. Antiparasitic Activity. In another work, the effect of $T$. broussonetii EOs was assessed on the experimental transmission of Toxoplasma gondii cysts in mice. These oils were administered orally $(20 \mu \mathrm{g} / \mathrm{animal})$ at the infection time and thereafter for several days. In mice given the essential oils, no cyst was observed. In addition, no disorder was noted in the control animals given the thyme EOs [30] (Table 6).

3.3.11. Insecticidal Activity. The insecticidal activity of T. broussonetii EO was screened using the contact toxicity assay. The oil proved insecticidal effectiveness against Tribolium castaneum Herbst. After $24 \mathrm{~h}$ of treatment, the $\mathrm{LD}_{50}$ and $\mathrm{LD}_{90}$ were 0.08 and $0.19 \mu \mathrm{l} / \mathrm{cm}^{2}$, respectively. These results suggest that the contents of thyme EOs, in particular those obtained from the genus Thymus, have a good botanical bioinsecticide potential against Tribolium castaneum Herbst [29].

The insecticidal activity of the EO of this plant was examined against Tribolium castanum by the contact toxicity assay. The essential oil exhibited the highest insecticidal activity with a median lethal time $\left(\mathrm{TL}_{50}\right)$ of $1.5 \mu \mathrm{L} / \mathrm{cm}^{2}$ with $\mathrm{LT}_{50}$ (lethal time required to kill $50 \%$ of the exposed insects) values of $30,36(24,62-38,48)$ at a dose of $1 \mu \mathrm{l} / \mathrm{cm}^{2}$ and $4,81(3,8-5,99)$ at a dose of $1,5 \mu \mathrm{l} / \mathrm{cm}^{2}$, respectively and a $\mathrm{LT}_{90}$ (lethal time required to kill $90 \%$ of the exposed insects) of $222,78(138,62-475,59)$ at a dose of $1 \mu \mathrm{l} / \mathrm{cm}^{2}$ and 16,07 (11,4-30,08), respectively. The Thymus broussonnetii Boiss EO could act as a substitute for biopesticide and reduce the harmful impact of chemical insecticides on the environment and humans [27] (Table 6).
3.3.12. Immunological and Behavioral Effects. The antinociceptive effect of aqueous, butanol, and ethyl acetate extracts of $T$. broussonetii was studied using thermal and chemical nociception models and naloxone (a nonselective opioid antagonist) to determine the role of the opioid system in the antinociceptive activity of these extracts. To determine the phytoconstituents of the extracts tested, phytochemical screening was carried out, which revealed the presence of tannins in all the extracts. Quinones, saponins, and flavonoids were detected in butanol and ethyl acetate extracts, while terpenes were only identified in the ethyl acetate extract [31].

The butanol and aqueous extracts showed an antinociceptive effect in both phases of formalin $(50-300 \mathrm{mg} /$ $\mathrm{kg}$ ), tail immersion, and writing tests. At the same time, only the nociceptive response of the second phase was significantly reduced by the ethyl acetate extract $(100-300 \mathrm{mg} / \mathrm{kg})$. In the first and second phases, the aqueous extract was the most effective, with $\mathrm{ED}_{50}$ values of 177 (147-200) and 134 (95-170) $\mathrm{mg} / \mathrm{kg}$, respectively. The aqueous extract $(200 \mathrm{mg} /$ $\mathrm{kg}$ ) showed a potent effect and significantly reduced the number of writhes induced by acetic acid, with $88.9 \%$ of writhes inhibition compared to those of ethyl acetate (69\%) and butanol (63\%) extracts. These obtained proved that T. broussonetii contains active compounds (polar and nonpolar) having antinociceptive activity with distinct mechanisms of action [31] (Table 6).

3.4. Toxicological Investigations. An acute toxicity screening was carried out for T. broussonetii EOs in order to verify their harmlessness to avoid a possible overdose and to properly determine the toxicological profile of the $T$. broussonetii species. This was assessed using the Leitchfield and Wilcoxon method, and the effective lethal dose $\left(\mathrm{LD}_{50}\right)$ was measured. Subsequently, signs of toxicity such as diarrhea, convulsion, piloerection, motor coordination, and behavioral changes (excitation and twitches) were determined. For the groups receiving the dose of $1 \mathrm{~g} / \mathrm{kg}$, the change in body weight was also determined. On the other hand, thymol $(36.7 \%)$ and borneol $(21.9 \%)$ were the two major compounds, followed by $p$-cymene $(7.6 \%)$ and $\beta$-pinene $(0.7 \%)$. At a dose of $2 \mathrm{mg} / \mathrm{kg}$, some cases of death and signs of toxicity were recorded. The $\mathrm{LD}_{90} \mathrm{~s}$ and $\mathrm{LD}_{50} \mathrm{~S}$ were estimated to be $7.31(5.64-13.54)$ and $4.47(3.6-6.72) \mathrm{g} /$ $\mathrm{kg}$, respectively [22].

\section{Conclusion and Perspectives}

Here, the phytochemistry, toxicology, and pharmacological properties of $T$. broussonetii were highlighted. Phytochemical studies of this species showed its richness in numerous bioactive compounds, exhibiting important biological effects. Pharmacological investigations confirmed the safety of this plant. However, these investigations must be further investigated using several toxicological reports at several different doses and time periods. Pharmacological biology explorations demonstrated that T. broussonetii essential oils and extracts exhibit important and remarkably antimicrobial, anticancer and, anti-inflammatory properties. 
These investigations were conducted using in vitro approaches, and therefore, further in vivo examinations should be performed to explore the pharmacological properties of T. broussonetii importantly. Moreover, mechanisms related to the biological effects of $T$. broussonetii and its bioactive compounds should also be explored to validate their pharmacodynamic actions.

\section{Data Availability}

The data used to support the findings of this study are included within the article.

\section{Conflicts of Interest}

The authors declare that they have no conflicts of interest.

\section{References}

[1] M. Valverde, R. El Género Thymus L (Labiatae) En Africa, Springer, Berlin, Germany, 1993.

[2] H. Ouhaddou, H. Boubaker, F. Msanda, and A. El Mousadik, "An ethnobotanical study of medicinal plants of the agadir ida ou tanane province (southwest Morocco)," Journal of Applied Bioscience, vol. 84, pp. 7707-7722, 2014.

[3] S. Belhaj, N. Chaachouay, and L. Zidane, "Ethnobotanical and toxicology study of medicinal plants used for the treatment of diabetes in the high Atlas central of Morocco," Journal of Pharmacy \& Pharmacognosy Research, vol. 9, pp. 619-662, 2021.

[4] A. Abbad, R. Belaqziz, K. Bekkouche, and M. Markouk, "Influence of temperature and water potential on laboratory germination of two Moroccan endemic thymes: Thymus maroccanus ball. And Thymus broussonetii Boiss," African Journal of Agricultural Research, vol. 6, pp. 4740-4745, 2011.

[5] H. O. H. Ouhaddou, A. Alaoui, and A. Sezgin, "Ethnobotanical survey of medicinal plants used for treating diabetes in agadir ida outanane region, southwestern Morocco," Arabian Journal of Medicinal and Aromatic Plants, vol. 6, pp. 72-86, 2020.

[6] S. Skalli, R. Hassikou, and M. Arahou, "An ethnobotanical survey of medicinal plants used for diabetes treatment in rabat, Morocco," Heliyon, vol. 5, Article ID e01421, 2019.

[7] J. Bellakhdar, Pharmacopée Marocaine Traditionnelle, Ibis Press, Newburyport, MA, USA, 1997.

[8] M. Tbatou, A. Belahyan, and R. Belahsen, "Wild edible plants traditionally used in the countryside of El jadida, coastal area in the center of Morocco," Life Sciences Leaflets, vol. 75, pp. 28-48, 2016.

[9] H. Briguiche and L. Zidane, "Ethnobotanical study of medicinal plants from el-jadida city (Morocco)," Lazaroa, vol. 37, pp. 145-151, 2016.

[10] R. Mehdioui and A. Kahouadji, "Etude ethnobotanique auprès de La population riveraine de La forêt d'Amsittène: cas de La commune d'Imi n'Tlit (province d'Essaouira)," Bulletin de l'Institut Scientifique, Section Sciences de la Vie, vol. 29, pp. 11-20, 2007.

[11] E. m. E. Ouariachi, E. mokhtar, I. Hamdani et al., "Chemical composition and antioxidant activity of essential oils of Thymus broussonetii Boiss. And Thymus algeriensis Boiss. From Morocco," Asian Pacific Journal of Tropical Disease, vol. 4, no. 4, pp. 281-286, 2014.
[12] A. Jaafari, H. A. Mouse, L. A. M'Bark et al., "Differential antitumor effect of essential oils and their major components of Thymus broussonettii: relationship to cell cycle and apoptosis induction," Herba Polonica, vol. 55, pp. 36-50, 2009.

[13] L. El Bouzidi, C. A. Jamali, K. Bekkouche et al., "Chemical composition, antioxidant and antimicrobial activities of essential oils obtained from wild and cultivated Moroccan Thymus species," Industrial Crops and Products, vol. 43, pp. 450-456, 2013.

[14] H. Boubaker, "Chemical characterization and antifungal activities of four Thymus species essential oils against postharvest fungal pathogens of citrus," Industrial Crops and Products, vol. 7, 2016.

[15] L. Ait M'Barek, H. Ait Mouse, A. Jaâfari et al., "Cytotoxic effect of essential oil of thyme (Thymus broussonettii) on the IGR-OV1 tumor cells resistant to chemotherapy," Brazilian Journal of Medical and Biological Research, vol. 40, pp. 1537-1544, 2007.

[16] A. Tantaoui-elaraki, N. Lattaoui, A. Errifi, and B. Benjilali, "Composition and antimicrobial activity of the essential oils of thymus broussonettii, T. zygisandT. Satureioides," Journal of Essential Oil Research, vol. 5, no. 1, pp. 45-53, 1993.

[17] S. E. A. Zerrifi, A. Kasrati, E. M. Redouane et al., "Essential oils from Moroccan plants as promising ecofriendly tools to control toxic cyanobacteria blooms," Industrial Crops and Products, vol. 143, Article ID 111922, 2020.

[18] A. Saad, M. Fadli, M. Bouaziz, A. Benharref, N.-E. Mezrioui, and L. Hassani, "Anticandidal activity of the essential oils of Thymus maroccanus and Thymus broussonetii and their synergism with amphotericin B and fluconazol," Phytomedicine, vol. 17, no. 13, pp. 1057-1060, 2010.

[19] R. Belaqziz, R. Harrak, A. Romane, and K. Oufdou, "Antimicrobial and insecticidal activities of the endemic Thymus broussonetti Boiss. and Thymus maroccanus ball," Records of Natural Products, vol. 8, 2010.

[20] C. A. Jamali, L. El Bouzidi, K. Bekkouche et al., "Chemical composition and antioxidant and anticandidal activities of essential oils from different wild Moroccan Thymus species," Chemistry and Biodiversity, vol. 9, no. 6, pp. 1188-1197, 2012.

[21] A. Jaafari, H. A. Mouse, E. M. Rakib et al., "Chemical composition and antitumor activity of different wild varieties of Moroccan thyme," Revista Brasileira de Farmacognosia, vol. 17, no. 4, 2007.

[22] K. Elhabazi, R. Aboufatima, A. Bensalah et al., "Acute toxicity of essential oils of two moroccan endemic species," Thymus Broussonetii and Thymus Leptobotrys, vol. 6, 2012.

[23] H. Chebli, M. Zaafrani, A. Batah et al., "Chemical composition and green anticorrosive potential of Thymus broussonnetii Boiss subsp. broussonnetii essential oils in hydrochloric acid medium," Journal of Bio- and Tribo-Corrosion, vol. 5, no. 1, p. 13, 2019.

[24] S. Belmalha, G. Echchgadda, J. Ibijbijen et al., "Characterizing the major morphological traits and chemical compositions in nine species of wild thyme from Morocco," European Journal of Scientific Research, vol. 145, p. 14, 2017.

[25] S. Ahlam, B. Fatima, O. Mohammed, A. Youssef, M. Lhou, and R. Abderrahmane, "Phytochemical screening and antioxidant activity of four moroccan thymus species: T. Leptobotrys Murb.” Aromatic Plants, vol. 12, 2015.

[26] B. Smahane, B. Mounyr, B. Faisl, M. Stephane, M. Sghir, and B. Dalila, "Antimicrobial activities of essential oil of five plant species from Morocco against some microbial strains," International Journal of Pharmacognosy and Phytochemical Research, vol. 8, p. 6, 2016. 
[27] A. El Hamdaoui, Y. Elmaati, A. Bouglad et al., "Contribution à La Caractérisation et à La Valorisation de Deux Espèces de Thym de l'arganeraie Du Sud Ouest Marocain," Actes 3ème Congrès Int. L'Arganier, vol. 8, pp. 1901-1906, 2015.

[28] H. Ismaili, S. Sosa, D. Brkic et al., "Topical anti-inflammatory activity of extracts and compounds from Thymus broussonettii," Journal of Pharmacy and Pharmacology, vol. 54, no. 8, pp. 1137-1140, 2002.

[29] C. Alaoui-Jamali, A. Kasrati, D. Leach, and A. Abbad, "Étude comparative de l'activité insecticide des huiles essentielles des espèces de thyms originaires du Sud-Ouest marocain," Phytothérapie, vol. 16, no. 5, pp. 268-274, 2018.

[30] A. Dahbi, B. Bellete, P. Flori et al., "The effect of essential oils from Thymus broussonetii Boiss on transmission of Toxoplasma gondii cysts in mice," Parasitology Research, vol. 107, no. 1, pp. 55-58, 2010.

[31] K. Elhabazi, A. Dicko, F. Desor, A. Dalal, C. Younos, and R. Soulimani, "Preliminary study on immunological and behavioural effects of Thymus broussonetii Boiss., an endemic species in Morocco," Journal of Ethnopharmacology, vol. 103, no. 3, pp. 413-419, 2006.

[32] M. Fennane, M. I. Tattou, and B. Valdés, "Catalogue des plantes vasculaires rares, menacées ou endémiques du maroc," Herbarium Mediterraneum Panormitanum, 1998.

[33] R. Belaqziz, R. Harrak, A. Romane, K. Oufdou, and M. A. E. ElFels, "Antimicrobial and insecticidal activities of the endemic Thymus broussonetti Boiss. and Thymus maroccanus ball," Records of Natural Products, vol. 4, p. 230, 2010.

[34] N. Lattaoui and A. Tantaoui-Elaraki, "Comparative kinetics of microbial destruction by the essential oils of Thymus broussonettii, T. zygisandT. Satureioides," Journal of Essential Oil Research, vol. 6, no. 2, pp. 165-171, 1994.

[35] A. Bouyahya, O. Belmehdi, A. Benjouad et al., "Pharmacological properties and mechanism insights of Moroccan anticancer medicinal plants: what are the next steps?" Industrial Crops and Products, vol. 147, Article ID 112198, 2020.

[36] H. Elbe, G. Yigitturk, T. Cavusoglu, T. Baygar, M. Ozgul Onal, and F. Ozturk, "Comparison of ultrastructural changes and the anticarcinogenic effects of thymol and carvacrol on ovarian cancer cells: which is more effective?" Ultrastructural Pathology, vol. 44, no. 2, pp. 193-202, 2020.

[37] K. Elhabazi, R. Aboufatima, A. Zyad et al., Study on the Antipyretic Activity of Thyme (Thymus Broussonetii) in Experimental Rats, Vol. 7, ResearchGate, Berlin, Germany, 2012.

[38] A. Pakdemirli, C. Karaca, T. Sever et al., "Carvacrol alters soluble factors in HCT-116 and HT-29 cell lines," Turkish Journal of Medical Sciences, vol. 50, pp. 271-276, 2020. 